\title{
The contribution of motor vehicle emissions to ambient fine particulate matter public health impacts in New York City: a health burden assessment
}

Iyad Kheirbek ${ }^{1 *}$, Jay Haney ${ }^{2}$, Sharon Douglas ${ }^{2}$, Kazuhiko Ito ${ }^{1}$ and Thomas Matte ${ }^{1}$

\begin{abstract}
Background: On-road vehicles are an important source of fine particulate matter $\left(\mathrm{PM}_{2.5}\right)$ in cities, but spatially varying traffic emissions and vulnerable populations make it difficult to assess impacts to inform policy and the public.

Methods: We estimated $\mathrm{PM}_{2.5}$-attributable mortality and morbidity from on-road vehicle generated air pollution in the New York City (NYC) region using high-spatial-resolution emissions estimates, air quality modeling, and local health incidence data to evaluate variations in impacts by vehicle class, neighborhood, and area socioeconomic status. We developed multiple 'zero-out' emission scenarios focused on regional and local cars, trucks, and buses in the NYC region. We simulated PM $_{2.5}$ concentrations using the Community Multi-scale Air Quality Model at a 1-km spatial resolution over NYC and combined modeled estimates with monitored data from 2010 to 2012. We applied health impact functions and local health data to quantify the $\mathrm{PM}_{2.5}$-attributable health burden on NYC residents within 42 city neighborhoods.
\end{abstract}

Results: We estimate that all on-road mobile sources in the NYC region contribute to 320 (95\% Confidence Interval (Cl): 220-420) deaths and 870 (95\% Cl: 440-1280) hospitalizations and emergency department visits annually within NYC due to PM 2.5 exposures, accounting for 5850 (95\% Cl: 4020-7620) years of life lost. Trucks and buses within NYC accounted for the largest share of on-road mobile-attributable ambient $\mathrm{PM}_{2.5}$, contributing up to $14.9 \%$ of annual average levels across 1-km grid cells, and were associated with 170 (95\% Cl: 110-220) $\mathrm{PM}_{2.5^{-}}$ attributable deaths each year. These contributions were not evenly distributed, with high poverty neighborhoods experiencing a larger share of the exposure and health burden than low poverty neighborhoods.

Conclusion: Reducing motor vehicle emissions, especially from trucks and buses, could produce significant health benefits and reduce disparities in impacts. Our high-spatial-resolution modeling approach could improve assessment of on-road vehicle health impacts in other cities.

Keywords: Fine particulate matter (PM2.5), Community multiscale air quality model (CMAQ), BenMAP, Traffic, Health impact assessment, Air quality management

Abbreviations: BenMAP, Environmental Benefits Mapping and Analysis Program; BPM, Best Practices Model; Cl, Confidence interval; CMAQ, Community Multi-scale Air Quality Model; CO, Carbon monoxide; DEP, New York City (Continued on next page)

\footnotetext{
* Correspondence: ikheirbe@health.nyc.gov

${ }^{1}$ New York City Department of Health and Mental Hygiene, Bureau of

Environmental Surveillance and Policy, 125 Worth Street, Third Flr. CN-34E,

New York, NY 10013, USA

Full list of author information is available at the end of the article
} 


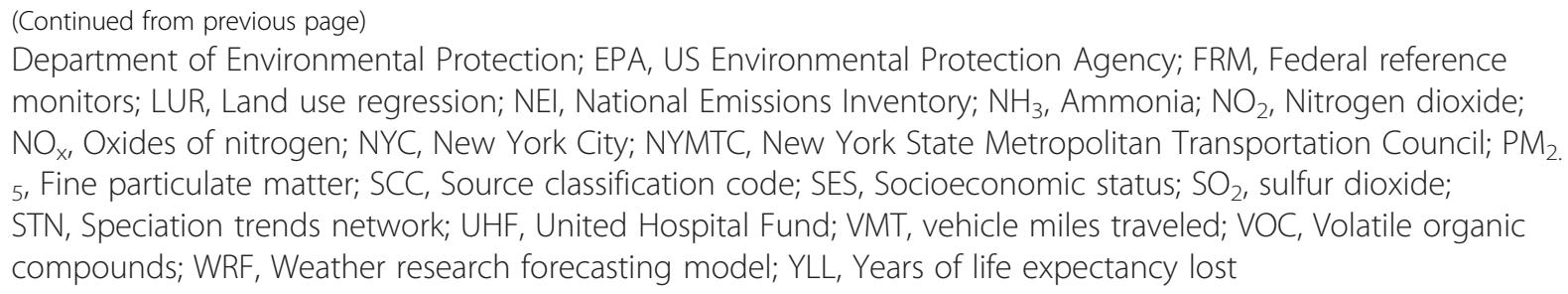

\section{Background}

Fine particulate matter $\left(\mathrm{PM}_{2.5}\right)$ is a common air pollutant that has been associated with multiple adverse health outcomes [1]. Despite declines in $\mathrm{PM}_{2.5}$ concentrations in New York City (NYC), recent estimates suggest ambient levels contribute to large numbers of avoidable premature deaths and diseases [2], and studies have shown a significant association between trafficrelated air pollution and premature mortality [3]. Other studies have shown increased risk of respiratory and cardiovascular disease associated with close residential proximity to traffic pollution $[4,5]$.

Air quality public health impact analyses have emerged as an important approach for estimating the public health toll of air pollution, comparing its risks to other public health threats, and evaluating strategies and regulations designed to reduce exposures. Assessing source-specific contributions to health burdens can help prioritize strategies that offer the maximum benefit and minimize inequalities [6]. Typically, air quality and health modeling analyses performed for regulatory decision making or policy research are conducted at coarse spatial resolutions (e.g. 12-km, 36-km, county-level) [7-9]. However, analyses at these spatial scales do not allow researchers and policymakers to examine relationships between population health susceptibility and air pollution exposures, both of which can spatially vary substantively within a city at smaller scales. To address these limitations in the regulatory methodology, new modeling approaches are needed to combine information on within city disparities in both exposures and health.

While regulatory efforts have reduced emissions, on-road mobile sources continue to contribute to ambient levels of multiple air pollutants in NYC. Local source apportionment analyses conducted using data from the early 2000s suggested that $16-39 \%$ of ambient $\mathrm{PM}_{2.5}$ concentrations in NYC were attributable to traffic sources $[10,11]$. More recently, saturation sampling and land-use regression (LUR) modeling have demonstrated that traffic emissions density is an important contributor to within-city spatial variation in $\mathrm{PM}_{2.5}$, nitrogen dioxide $\left(\mathrm{NO}_{2}\right)$ and black carbon levels in NYC [12]. While these studies provide useful information on the relative importance of local source sectors, source apportionment analyses using monitor data are limited by the locations of monitors, while LUR models that use surrogate indicators of emissions do not account for dispersion and chemical transformation processes and therefore may not be well-suited to quantify source contributions to ambient levels. Deterministic models of emissions, dispersion and chemical transformation processes can estimate exposure increments from individual sources, and recent developments in methods using high resolution modeling in urban areas can better represent spatial gradients across neighborhoods with wide variation in baseline health incidence [13, 14].

NYC, with high densities of populations living near emissions sources, also has the highest density of primary $\mathrm{PM}_{2.5}$ emissions among large US cities [15]. Wide variation in baseline health rates exist across the city, strongly associated with area-based poverty concentration [16]. Recent sustainability planning efforts in NYC have focused on reducing $\mathrm{PM}_{2.5}$ levels overall while shrinking disparities in exposures [17]. However, to date, limited data exist on the health burden from on-road mobile source emissions, the relative importance of regional as compared to local sources, or the differential contributions of differing vehicle classes. This information provides valuable context for developing and prioritizing local policy for cities.

To evaluate the extent and variation of $\mathrm{PM}_{2.5}$-attributable mortality and morbidity due to emissions of on-road mobile source primary $\mathrm{PM}_{2.5}$ and $\mathrm{PM}_{2.5}$ precursors in the region, we applied a local-scale air quality and health modeling framework to the five counties of NYC and the 28-county NYC metropolitan region. We estimated separately the $\mathrm{PM}_{2.5}$-attributable burden from emissions from all motor vehicle traffic in the region and within NYC, trucks and buses within NYC, cars within NYC, and on-road mobile sources in the region outside of NYC. We then explored the disparity in air quality and public health burden across neighborhoods of differing poverty status.

\section{Methods}

We built an air quality and public health modeling framework for on-road mobile sources that included emissions inventory development and spatial allocation, meteorological and air quality modeling, combining modeling results and monitored data, and health impact calculations by modifying a prior framework used in an evaluation of heating fuel conversions in buildings [14, 18] (Fig. 1). 


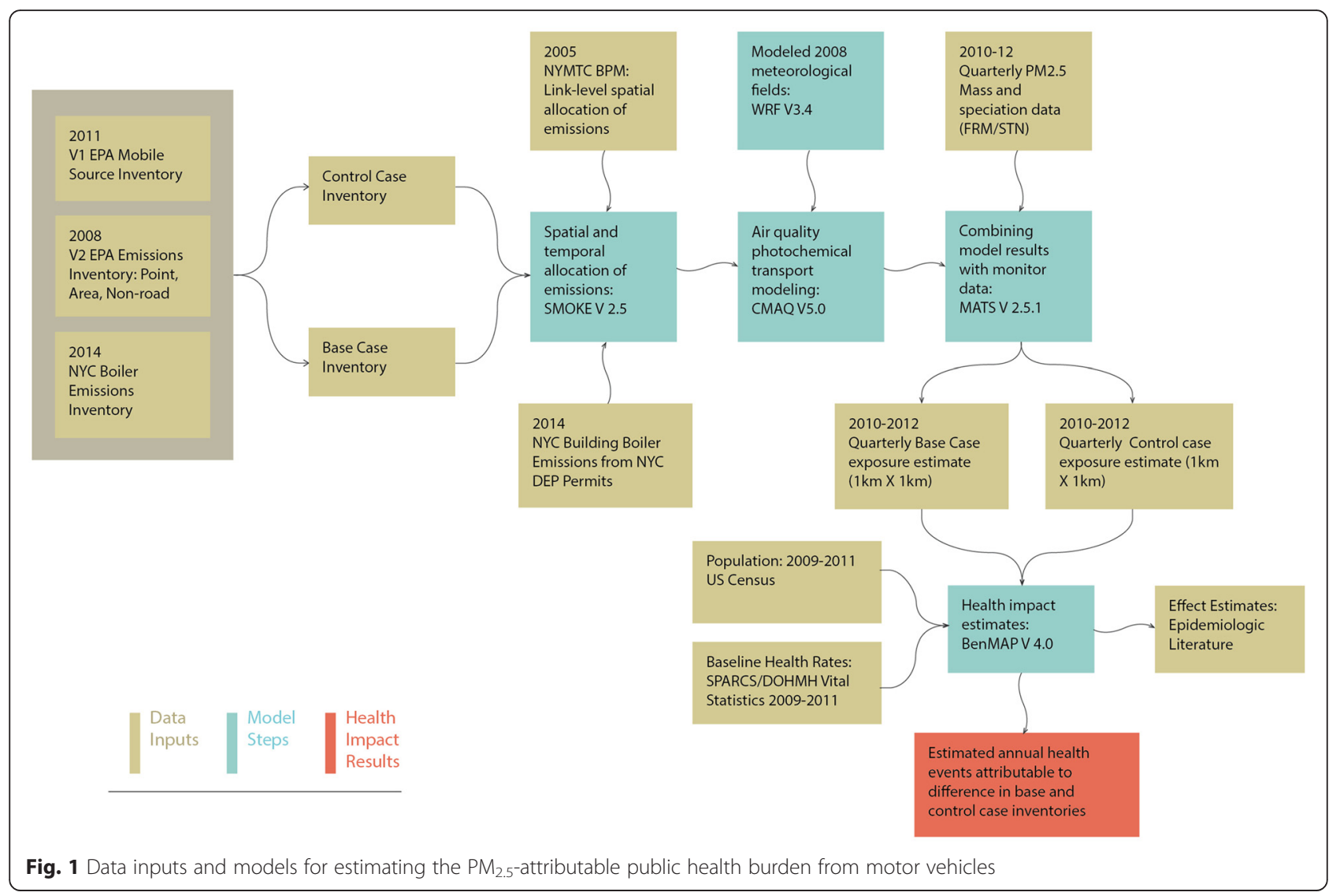

\section{Emissions inventory preparation}

To characterize baseline conditions we built inventories from EPA's 2008 National Emissions Inventory (NEI) modeling platform [19]. Described in detail elsewhere, we prepared emissions for three nested grids centered over NYC at $15-\mathrm{km}$ national-scale, 5-km regional-scale, and 1$\mathrm{km}$ local-scale horizontal resolution [18]. We replaced emissions for the on-road mobile source and building heating sectors in the 2008 NEI with more recent, refined local data to better reflect their spatial patterns.

We estimated on-road mobile source emissions using the most recently available county-level data from EPA's 2011 National Emissions Inventory [20]. County-level emission estimates were spatially allocated to road links in proportion to modeled, link-level vehicle miles traveled from the 2005 New York State Metropolitan Transportation Council (NYMTC) Best Practices Model (BPM) [21]. Despite the relatively older time frame of the NYMTC BPM model, it provided the most recently available modeled counts for cars, trucks, and buses for links within the 28 counties in the NYC region and we assumed that relative spatial patterns in traffic density were reasonably stable between 2005 and 2011. To improve the spatial accuracy within the five NYC counties, the NYMTC shapefile was spatially aligned to the TeleAtlas street segment database within ArcGIS 9.2 Data \& Maps.
For grid cells within the $1-\mathrm{km}$ and $5-\mathrm{km}$ modeling grids, we calculated on-road mobile source emissions of total volatile organic compounds (VOC), oxides of nitrogen $\left(\mathrm{NO}_{\mathrm{x}}\right)$, carbon monoxide $(\mathrm{CO})$, sulfur dioxide $\left(\mathrm{SO}_{2}\right)$, ammonia $\left(\mathrm{NH}_{3}\right)$, primary $\mathrm{PM}_{2.5}$, and $\mathrm{PM}_{2.5}$ and VOC species profiles. Emissions were allocated do grid cells by first computing at each roadway link the vehicle miles traveled (VMT) by vehicle class (car, truck, bus) by multiplying the annual NYMTC vehicle-specific counts by the length of the segment. We then created ratios, by vehicle type, of the VMTs on each link to the total VMTs in the county. Second, we downloaded the on-road mobile source portion of the 2011 EPA NEI (V1) [20] and matched the Source Classification Code (SCC) subcategories to NYMTC car, truck, and bus categories. All light-duty and heavy-duty gasoline and diesel truck SCC codes were placed in the 'truck' category, while lightduty gasoline and diesel vehicles and motorcycles were included in the 'car' category. The heavy duty diesel bus SCC codes were included in the 'bus' category. Third, we estimated annual link-level emissions for each pollutant and vehicle type by multiplying the county-level emissions by the ratio of the VMTs on each link to the total VMTs in the county. Fourth, we created emissions totals for each pollutant/vehicle type in each $1-\mathrm{km}$ and $5-\mathrm{km}$ grid cell by summing the emissions from links that fell 
within each grid cell. For links that crossed multiple grid cells, emissions were apportioned based on the fraction of the link's length included in each grid cell. Finally, because NYMTC does not include VMT breakdowns for categories within 'car,' 'truck', and 'bus,' we approximated these by extracting the county-level VMT data from EPA's 2008 VMT database [22], then calculated the VMT fractions for gasoline, light- and heavy-duty diesel vehicles. This was then used to assign $\mathrm{VOC}$ and $\mathrm{PM}_{2.5}$ speciation profiles by estimating the $\mathrm{VOC}$ and $\mathrm{PM}_{2.5}$ emissions for gasoline, light- and heavy-duty diesel vehicles using the VMT fractions for each vehicle type, and then assigning the corresponding $\mathrm{PM}_{2.5}$ and $\mathrm{VOC}$ speciation profiles to the each of the categories.

To more accurately represent current building boiler emissions in NYC overall and the within the city, we updated the 2008 NEI for Nos. 2, 4, and 6 heating oil boilers using local permit data reflecting emissions as of 2015. These methods are described in detail elsewhere [14]. Briefly, emissions from Nos. 2, 4, and 6 boilers were calculated using EPA emissions factors [23] and NYC Department of Environmental Protection (NYCDEP) permit data that identify the location and heat throughput of the boiler. No. 4 emissions factors were adjusted to account for NYC-regulated 1500 ppm sulfur content, while No.2 emissions factors assumed a 15 ppm sulfur content, consistent with New York State-wide limits [24]. As many buildings are undergoing conversions of Nos. 4 and 6 boilers to comply with recent regulations [25], we reviewed the permit database as of December 2014, and assigned each building an annual emissions value based on the fuel they were using at that time and spatially allocated these emissions based on boiler address. To estimate emissions from No.2 boilers below the permitting threshold (350,000 Btu), we used NEI emissions not accounted for in the permits, allocating to buildings using surrogate data on building area and the county-specific percent of buildings using No.2 heating oil.

We prepared CMAQ-ready emissions by merging estimates for biogenic sources and all anthropogenic sectors with the updated on-road mobile source inventory and fuel oil boiler inventories. These emissions were processed using the Sparse Matrix Operator Kernel Emissions processor software (version 3.1 ) to create the air quality modeling input for the base case. We created three additional inventories reflecting removal of specific source categories: zeroing out all motor vehicle emissions within NYC (Sc1), zeroing out truck and bus emissions within NYC (Sc2), and zeroing out all motor vehicles in the 23 counties that surround the five NYC counties (Sc3).

\section{Air quality modeling}

Detailed discussion of the application and evaluation of the meteorological and air quality modeling system has been presented elsewhere [18]. In short, meteorological fields for all grids were developed for 2008 using the Weather Research and Forecasting Model (WRF). Air quality modeling was conducted using the Community Multi-Scale Air Quality Model (CMAQ) version 5.0. Annual CMAQ simulations were conducted separately for the base case and each of the three zero-out scenarios and we utilized the daily simulated $\mathrm{PM}_{2.5}$ mass and species concentrations from the $1-\mathrm{km}$ grid cells over NYC for subsequent health burden analyses.

\section{Health burden analysis}

Exposure estimates at a 1-km resolution were developed using EPA's Modeled Attainment Test Software (MATS) [26]. MATS combines the CMAQ modeled output with monitored $\mathrm{PM}_{2.5}$ mass and speciation data to create combined spatial surfaces, providing exposure estimates that use the monitor data but leverages the CMAQ simulated values to better estimate spatial gradients and surface response to changes in emissions. We developed 3 year, quarterly average estimates based on 2010-2012 EPA federal reference monitors (FRM) and speciation trends network (STN) monitors and the daily CMAQ modeling.

We computed the change in number of health events due to changes in $\mathrm{PM}_{2.5}$ concentrations between the base case and each of the three scenarios (Sc1, Sc2, and Sc3) using health impact functions [27, 28]. We applied risk functions for all-cause mortality from chronic exposure among those above 30 years of age [29], emergency department visits for asthma from acute exposure among all age groups (seasonally-specific risk estimates) [30], hospitalizations for all respiratory outcomes from acute exposure among those above 20 years of age (seasonally specific risk estimates for populations above 65 years of age) [31, 32], and hospitalizations for all cardiovascular outcomes from acute exposure among those above 40 years of age (seasonally specific risk estimates) [33]. Risk functions were chosen based on those determined to be most relevant to current New York City populations by selecting those published in peerreviewed scientific journals and favoring those conducted in New York City when possible. We utilized NYC-specific risk functions for $\mathrm{PM}_{2.5}$-attributable emergency department visits for asthma and hospitalizations for cardiovascular disease. When local studies were not available, we used recent large, multi-city studies or those included in EPA risk analyses [34]. Baseline health data were obtained for 2009-2011 from the NYC Department of Health and Mental Hygiene Bureau of Vital Statistics and the New York Statewide Planning and Research Cooperative System, summarized across 22 age and sex groups within each of 42 United Hospital Fund (UHF) neighborhoods (zip code aggregates). Additional 
details on risk estimate selection and baseline health data is described elsewhere [27]. Population data for the same age/sex/neighborhood groups were calculated based on the US Census Bureau Population Estimate program [35]. We estimated 3 year, quarterly average health impacts of each of the scenarios within each of the 42 neighborhoods and summed the quarterly estimates to produce annual burdens. All health impact calculations were performed on a quarterly basis using EPA's Benefits Mapping and Analysis Program (BenMAP) version 4.067 [36]. Further detail on our methodological choices for estimating the public health burden of $\mathrm{PM}_{2.5}$ on NYC residents can be found elsewhere [27].

To estimate years of life expectancy lost (YLL) we calculated life expectancy for 5 year age groupings using the city-wide, baseline mortality rates and standard abridged life table methods from the Centers for Disease Control and Prevention [37]. Years of life lost due to exposures associated with each scenario were calculated by multiplying the number of deaths in each age group attributable to the change in $\mathrm{PM}_{2.5}$ by the remaining life expectancy, then summing across all ages.

We first report the impacts on a citywide basis of removing all traffic in the 28-county region (adding Sc1 heath impacts to Sc3 health impacts), all traffic within NYC (Sc1), trucks and buses within NYC (Sc2), cars within NYC (subtracting Sc2 health impacts from Sc1 health impacts) and traffic from sources within the region but outside of NYC (Sc3). We explore correlations between on-road mobile source category contributions to ambient $\mathrm{PM}_{2.5}$ and neighborhood poverty then grouped neighborhoods based on percent of population residing under the federal poverty threshold (Low: 0$10 \%$, Medium: $10-20 \%$, High: $20-30 \%$, and Very High $>30 \%$ ), calculated using the 2008-2012 American Community Survey. We report gradients in $\mathrm{PM}_{2.5}$ concentrations, rates of $\mathrm{PM}_{2.5}$-attributable health outcomes, and percent contribution to the total number of health events by neighborhood poverty level.

\section{Results}

Emissions from motor vehicles within NYC produced 1817 tons of primary $\mathrm{PM}_{2.5}, 43,934$ tons of $\mathrm{NO}_{\mathrm{x}}, 20,613$ tons of total VOCs, and 336 tons of $\mathrm{SO}_{2}$, annually, accounting for $17.5,38.3,21.9$, and $4.6 \%$ of all local pollutant emissions, respectively. Of the primary $\mathrm{PM}_{2.5}$ emissions produced by motor vehicles, the majority are produced by trucks and buses, accounting for $12.8 \%$ of all local primary $\mathrm{PM}_{2.5}$ emissions. Based on the CMAQ model alone, primary $\mathrm{PM}_{2.5}$ concentrations attributable to truck and bus emissions within NYC contributed to an average of $27 \%$ of total $\mathrm{PM}_{2.5}$ concentrations from all on-road mobile sources in the region. Secondarily generated $\mathrm{PM}_{2.5}$ from truck and bus precursor emissions within NYC accounted for an average of $12 \%$ of total $\mathrm{PM}_{2.5}$ concentrations from all on-road mobile sources in the region (Additional file 1: Table S1). Cars within NYC contributed to an average of 10 and $25 \%$ of total $\mathrm{PM}_{2.5}$ concentrations from all on-road mobile sources in the region due to primary and secondarily formed $\mathrm{PM}_{2.5}$, respectively (Additional file 1: Table S1). Based on link level NYMTC estimates within NYC, cars contributed $94 \%$ of city VMTs while trucks and buses accounted for $6 \%$.

Based on the combined model and monitor exposure surface, we estimate that traffic in the 28-county area contributed 0.38 to $2.60 \mu \mathrm{g} / \mathrm{m}^{3}$ across $1-\mathrm{km}$ grid cells within NYC, accounting for 3.9 to $22.7 \%$ of ambient $\mathrm{PM}_{2.5}$ levels (Fig. 2). Trucks and buses within NYC showed the largest within city contributions to ambient levels, accounting for 0.0 to $1.71 \mu \mathrm{g} / \mathrm{m}^{3}$ of $\mathrm{PM}_{2.5}$, or 0.0 to $14.9 \%$ of $\mathrm{PM}_{2.5}$ concentrations. Emissions from cars within NYC and regional traffic (outside NYC) showed less of a contribution, with regional traffic mainly impacting grid cells along the edges of the city.

We estimate that, each year, emissions from on-road mobile sources within the five NYC counties contribute to 260 (95\% CI: 180, 340) $\mathrm{PM}_{2.5}$-attributable deaths from chronic $\mathrm{PM}_{2.5}$ exposure and 720 (95 \% CI: 380, 1050) $\mathrm{PM}_{2.5}$-attributable emergency room visits and hospital admissions due to respiratory and cardiovascular outcomes from acute exposure (Table 1). Among these, emissions from buses and trucks account for the largest share of the city-wide burden, contributing to 170 (95\% CI: 110, 220) $\mathrm{PM}_{2.5}$-attributable deaths each year while cars contributed to 100 (95 \% CI: 70, 120) PM $_{2.5}$-attributable deaths each year. On-road mobile sources in the metropolitan area outside of the five NYC counties contribute to an additional 60 (95\% CI: 40, 80) $\mathrm{PM}_{2.5}$-attributable deaths each year and 150 (95\% CI: 70, 220) $\mathrm{PM}_{2.5}$-attributable morbidity outcomes each year. Overall, we estimate $\mathrm{PM}_{2.5}$ exposures from on-road mobile sources in the metropolitan region contribute to 320 (95 \% CI: 220, 420) $\mathrm{PM}_{2.5}$-attributable deaths each year within NYC, contributing to 5850 (95\% CI: 4020, 7680) life years lost annually. The confidence intervals reported here only reflect those from the risk estimates derived from the epidemiologic studies and do not account for uncertainties in the other analysis steps.

We observed only a weak relationship between baseline $\mathrm{PM}_{2.5}$ concentrations and neighborhood poverty status, due to variable levels of $\mathrm{PM}_{2.5}$ across high income neighborhoods (Fig. 3). Affluent neighborhoods in NYC include many densely developed areas in Manhattan with high source density as well as more suburban neighborhoods with fewer emissions in Staten Island and Queens. However, there is a stronger relationship between on-road mobile-source-attributable $\mathrm{PM}_{2.5}$ and 


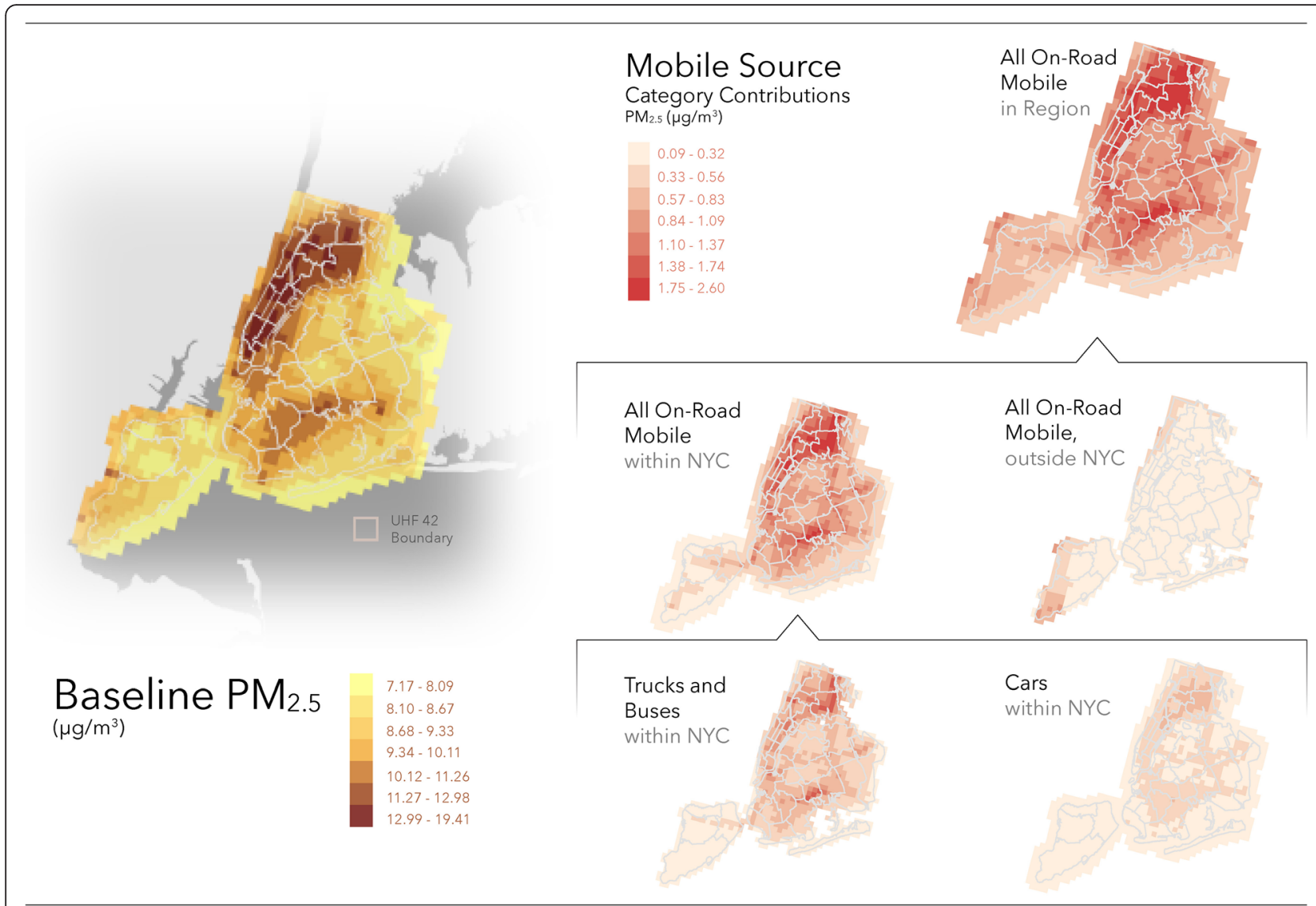

Fig. 2 Estimated $\mathrm{PM}_{2.5}$ levels in the Base Case and contributions to ambient levels from on-road mobile source categories (1-km resolution)

neighborhood poverty. This relationship is consistent for both bus/truck-attributable $\mathrm{PM}_{2.5}$ and car-attributable $\mathrm{PM}_{2.5}$, although a steeper gradient is found for bus/ truck-attributable $\mathrm{PM}_{2.5}$ (average absolute difference in impact between low and high poverty neighborhoods of $0.36 \mu \mathrm{g} / \mathrm{m}^{3}$ for trucks/buses and $0.22 \mu \mathrm{g} / \mathrm{m}^{3}$ for cars), reflecting high densities of truck traffic in lowincome neighborhoods.

There are large disparities in $\mathrm{PM}_{2.5}$-attributable health outcomes across neighborhoods with variable poverty status (Table 2). Across all source categories, higher mobile source $\mathrm{PM}_{2.5}$-attributable rates of morbidity and mortality are found in high poverty neighborhoods as compared to low poverty neighborhoods. This is due to the large disparity in the underlying rates of morbidity and mortality and higher on-road mobile source impacts on $\mathrm{PM}_{2.5}$ concentrations. The widest disparities are found for $\mathrm{PM}_{2.5}$-attributable emergency department visits for asthma. Onroad mobile sources in the region contribute to rates of $\mathrm{PM}_{2.5}$-attributable asthma emergency department visits that are 8.3 times higher in the very high poverty neighborhoods relative to low poverty neighborhoods, due to high source density and relatively high asthma morbidity rates in these communities. The percent of incidences due to on-road mobile sources, which reflect the impacts of sources on neighborhood $\mathrm{PM}_{2.5}$ levels, also showed disparities across neighborhoods of varying poverty status, with higher percentages in lower income neighborhoods across all source categories, except regional traffic emissions outside of NYC. Regional traffic emissions did not produce large gradients in the percent of incidences across neighborhoods of varying poverty status due to relatively even impacts on $\mathrm{PM}_{2.5}$ concentrations across the city, with slightly higher impacts on $\mathrm{PM}_{2.5}$ concentrations in some grid cells along the edges of the City in higher income neighborhoods of Manhattan and the northern Bronx.

\section{Discussion}

In this study, we applied a high-spatial-resolution modeling framework to assess the impacts of on-road mobile source generated primary $\mathrm{PM}_{2.5}$ and $\mathrm{PM}_{2.5}$ precursors on NYC populations. We estimated that over 300 deaths each year in the five counties of NYC are due to $\mathrm{PM}_{2.5}$ exposures related to motor vehicle emissions in the 28county region, contributing to 5850 YLL annually. These exposures also contribute to almost 900 emergency department visits and hospitalizations for respiratory and cardiovascular disease annually. Overall, on-road mobile 
Table 1 City-wide $\mathrm{PM}_{2.5}$-attributable health burdens of on-road mobile source emissions

\begin{tabular}{|c|c|c|c|c|c|}
\hline & \multicolumn{5}{|c|}{ Count $(95 \% \mathrm{Cl})$, percent of all events $(95 \% \mathrm{Cl})$, percent of $\mathrm{PM}_{2.5}$-attributable events $(95 \% \mathrm{Cl}$ ) } \\
\hline & $\begin{array}{l}\text { All motor vehicles in metropolitan region } \\
\text { (Sc1 health impacts plus Sc3 health impacts) }\end{array}$ & $\begin{array}{l}\text { All motor vehicles in NYC } \\
\text { (Sc1 health impacts) }\end{array}$ & $\begin{array}{l}\text { Buses and trucks in NYC } \\
\text { (Sc2 health impacts) }\end{array}$ & $\begin{array}{l}\text { Cars in NYC (Sc1 health impacts } \\
\text { minus Sc2 health impacts) }\end{array}$ & $\begin{array}{l}\text { All motor vehicles outside } \\
\text { NYC (Sc3 impacts) }\end{array}$ \\
\hline $\begin{array}{l}\text { Emergency Room Visits, Respiratory } \\
\text { (All Ages, acute exposure) }\end{array}$ & $\begin{array}{l}660(380,940), \\
0.76 \%(0.44 \%, 1.1 \%) \\
13.11 \%(7.5 \%, 18.6 \%)\end{array}$ & $\begin{array}{l}550(320,780), \\
0.64 \%(0.37 \%, 0.90 \%), \\
10.94 \%(6.3 \%, 15.5 \%)\end{array}$ & $\begin{array}{l}360(210,510), \\
0.42 \%(0.24 \%, 0.59 \%) \\
7.19 \%(4.17 \%, 10.12 \%)\end{array}$ & $\begin{array}{l}190(100,270), \\
0.22 \%(0.12 \%, 0.31 \%), \\
3.75 \%(1.98 \%, 5.36 \%)\end{array}$ & $\begin{array}{l}110(60,160), \\
0.13 \%(0.07 \%, 0.19 \%), \\
2.17 \%(1.19 \%, 3.17 \%)\end{array}$ \\
\hline $\begin{array}{l}\text { Hospital Admissions, Cardiovascular } \\
\text { (Ages } 40 \text { and above, acute exposure) }\end{array}$ & $\begin{array}{l}90(20,150), \\
0.14 \%(0.03 \%, 0.25 \%), \\
13.32 \%(3.1 \%, 23.0 \%)\end{array}$ & $\begin{array}{l}70(20,120), \\
0.12 \%(0.03 \%, 0.20 \% \\
10.94 \%(3.1 \%, 18.4 \%)\end{array}$ & $\begin{array}{l}40(10,80) \\
0.07 \%(0.02 \%, 0.13 \%) \\
6.84 \%(1.53 \%, 12.27 \%)\end{array}$ & $\begin{array}{l}30(10,50), \\
0.04 \%(0.02 \%, 0.08 \%), \\
4.09 \%(1.53 \%, 7.67 \%)\end{array}$ & $\begin{array}{l}20(4,30), \\
0.03 \%(0.01 \%, 0.05 \%), \\
2.41 \%(0.61 \%, 4.60 \%)\end{array}$ \\
\hline $\begin{array}{l}\text { Hospital Admissions, Respiratory } \\
\text { (Ages } 20 \text { and above, acute exposure) }\end{array}$ & $\begin{array}{l}120(40,190), \\
0.27 \%(0.09 \%, 0.45 \%), \\
12.96 \%(4.5 \%, 21.3 \%)\end{array}$ & $\begin{array}{l}100(40,150) \\
0.22 \%(0.09 \%, 0.35 \%) \\
10.68 \%(4.48 \%, 16.8 \%)\end{array}$ & $\begin{array}{l}60(20,100) \\
0.14 \%(0.05 \%, 0.24 \% \\
6.80 \%(2.24 \%, 11.21 \%)\end{array}$ & $\begin{array}{l}30(10,60), \\
0.08 \%(0.02 \%, 0.14 \%), \\
3.88 \%(1.12 \%, 6.73 \%)\end{array}$ & $\begin{array}{l}20(10,30), \\
0.05 \%(0.02 \%, 0.07 \%), \\
2.28 \%(1.12 \%, 3.36 \%)\end{array}$ \\
\hline $\begin{array}{l}\text { Premature Mortality (Ages } 30 \text { and } \\
\text { above, chronic exposure) }\end{array}$ & $\begin{array}{l}320(220,420) \\
0.68 \%(0.47 \%, 0.89 \%) \\
13.22 \%(9.14 \%, 17.44 \%)\end{array}$ & $\begin{array}{l}260(180,340), \\
0.55 \%(0.38 \%, 0.72 \%) \\
10.81 \%(7.48 \%, 14.12 \%)\end{array}$ & $\begin{array}{l}170(110,220), \\
0.35 \%(0.23 \%, 0.47 \%), \\
6.86 \%(4.57 \%, 9.14 \%)\end{array}$ & $\begin{array}{l}100(70,120), \\
0.2 \%(0.15 \%, 0.26 \%), \\
3.95 \%(2.91 \%, 4.98 \%)\end{array}$ & $\begin{array}{l}60(40,80), \\
0.12 \%(0.09 \%, 0.17 \%), \\
2.41 \%(1.67 \%, 3.32 \%)\end{array}$ \\
\hline $\begin{array}{l}\text { Years of Life Lost (Ages } 30 \text { and above, } \\
\text { chronic exposure) }\end{array}$ & $5850(4020,7680)$ & $4800(3300,6300)$ & $3050(2090,4000)$ & $1750(1210,2300)$ & $1050(720,1380)$ \\
\hline
\end{tabular}



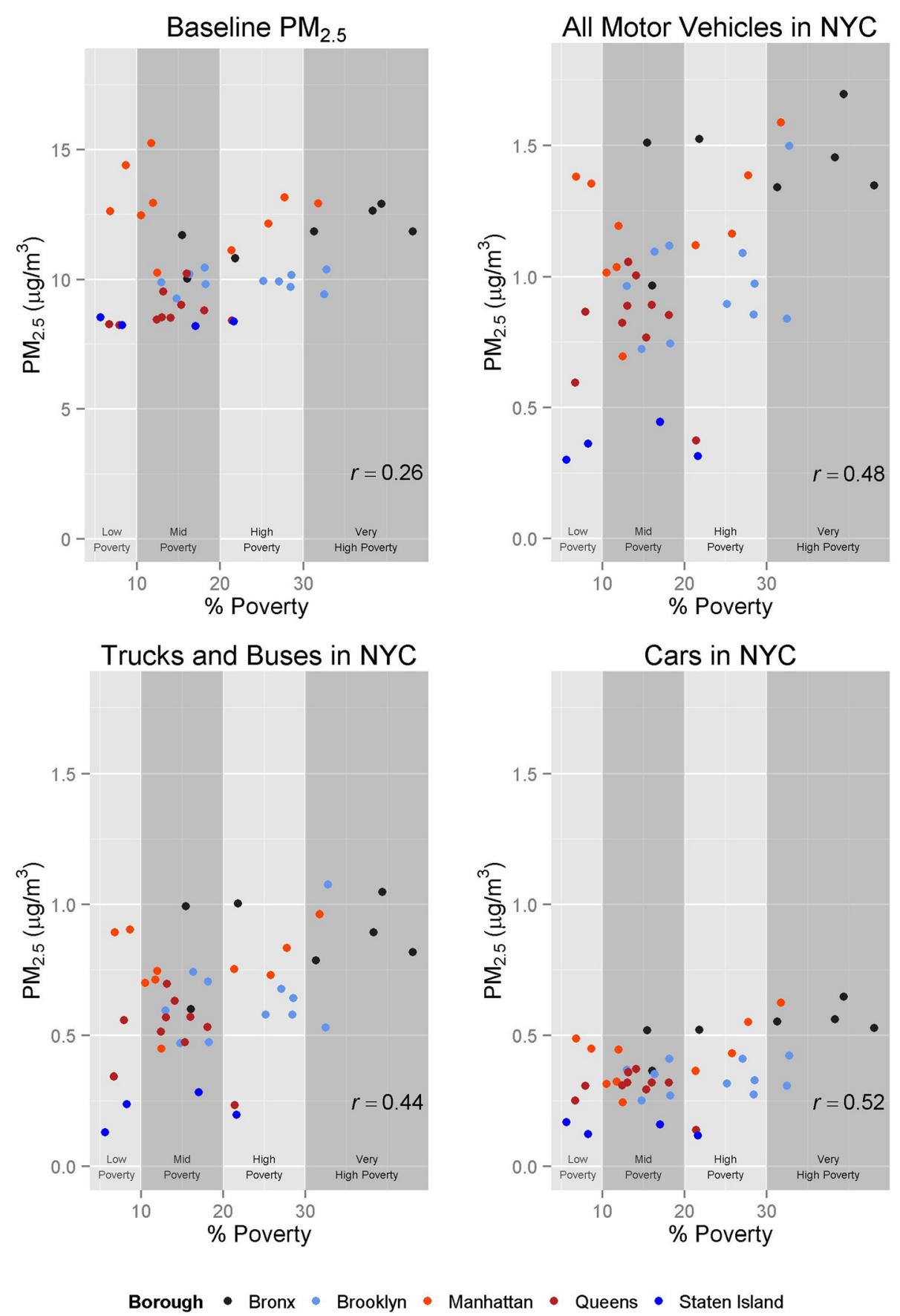

Fig. 3 Correlations of estimated baseline $\mathrm{PM}_{2.5}$ concentrations and contributions from on-road mobile sources with neighborhood poverty metrics

sources contribute to $0.7 \%$ of all deaths in NYC each year and $13.2 \%$ of $\mathrm{PM}_{2.5}$-attributable deaths, with the largest share of this impact due to emissions from trucks and buses on NYC roadways. Within NYC, we observed wide variation in incremental ambient $\mathrm{PM}_{2.5}$ contributions from traffic across 1-km grid cells. The largest impacts on air quality levels and health outcomes are found in the highest poverty areas of the city due to overlapping patterns of traffic density (particularly truck traffic) and higher underlying baseline incidence of morbidity.

Comparative analysis of traffic types demonstrated that trucks and buses, despite a much lower share of overall VMT within the city, contribute to the largest share of the on-road mobile source air quality burden with the majority of the primary $\mathrm{PM}_{2.5}$ emissions coming from 
Table 2 Distribution of $\mathrm{PM}_{2.5}$-attributable health outcomes due to on-road mobile sources by area poverty

\begin{tabular}{|c|c|c|c|c|c|}
\hline Metric & Source sector & $\begin{array}{l}\text { Low poverty } \\
(n=6)\end{array}$ & $\begin{array}{l}\text { Medium poverty } \\
(n=19)\end{array}$ & $\begin{array}{l}\text { High poverty } \\
(n=10)\end{array}$ & $\begin{array}{l}\text { Very high poverty } \\
(n=7)\end{array}$ \\
\hline \multirow{5}{*}{$\begin{array}{l}\text { Impacts on } \mathrm{PM}_{2.5} \text { Concentrations } \\
\left(\mathrm{\mu g} / \mathrm{m}^{3} \text {, percent of ambient concentrations) }\right.\end{array}$} & All on-road mobile sources in region & $1.09(10.9 \%)$ & $1.14(11.2 \%)$ & $1.21(11.6 \%)$ & $1.64(14.0 \%)$ \\
\hline & All on-road mobile sources in NYC & $0.81(8.1 \%)$ & $0.94(9.2 \%)$ & $0.97(9.3 \%)$ & $1.39(11.9 \%)$ \\
\hline & Trucks and buses in NYC & $0.51(5.1 \%)$ & $0.60(5.9 \%)$ & $0.62(6.0 \%)$ & $0.87(7.5 \%)$ \\
\hline & Cars in NYC & $0.30(3.0 \%)$ & $0.33(3.3 \%)$ & $0.35(3.3 \%)$ & $0.52(4.5 \%)$ \\
\hline & All on-road mobile sources outside NYC & $0.28(2.8 \%)$ & $0.21(2.0 \%)$ & $0.24(2.3 \%)$ & $0.25(2.1 \%)$ \\
\hline \multirow{5}{*}{$\begin{array}{l}\text { Impacts on Mortality among residents } \\
\text { above } 30 \text { years of age } \\
\text { PM }_{2.5} \text {-attributable rate per } 100,000 \text { residents } \\
(95 \% \mathrm{Cl}) \text {, } \\
\text { Percent of all events }(95 \% \mathrm{Cl}) \text {, } \\
\text { Percent of } \mathrm{PM}_{2.5} \text {-attributable events } \\
\text { (95\% Cl) }\end{array}$} & All on-road mobile sources in region & $\begin{array}{l}5.27(3.62,6.92) \\
0.58 \%(0.40 \%, 0.76 \%) \\
11.8 \%(8.1 \%, 15.4 \%)\end{array}$ & $\begin{array}{l}5.86(4.03,7.69) \\
0.63 \%(0.43 \%, 0.82 \%) \\
12.6 \%(8.7 \%, 16.6 \%)\end{array}$ & $\begin{array}{l}7.36(5.06,9.66) \\
0.7 \%(0.48 \%, 0.92 \%) \\
13.7 \%(9.4 \%, 17.9 \%)\end{array}$ & $\begin{array}{l}8.98(6.17,11.78) \\
0.88 \%(0.60 \%, 1.15 \%) \\
15.3 \%(10.5 \%, 20.1 \%)\end{array}$ \\
\hline & All on-road mobile sources in NYC & $\begin{array}{l}3.92(2.69,5.14) \\
0.43 \%(0.30 \%, 0.57 \%) \\
8.7 \%(6 \%, 11.5 \%)\end{array}$ & $\begin{array}{l}4.81(3.31,6.32) \\
0.52 \%(0.35 \%, 0.68 \%) \\
10.4 \%(7.1 \%, 13.6 \%)\end{array}$ & $\begin{array}{l}6.03(4.14,7.92) \\
0.57 \%(0.39 \%, 0.75 \%) \\
11.2 \%(7.7 \%, 14.7 \%)\end{array}$ & $\begin{array}{l}7.6(5.22,9.97) \\
0.74 \%(0.51 \%, 0.97 \%) \\
12.9 \%(8.9 \%, 17 \%)\end{array}$ \\
\hline & Trucks and buses in NYC & $\begin{array}{l}2.51(1.72,3.29) \\
0.28 \%(0.19 \%, 0.36 \%) \\
5.6 \%(3.8 \%, 7.3 \%)\end{array}$ & $\begin{array}{l}3.07(2.11,4.03) \\
0.33 \%(0.23 \%, 0.43 \%) \\
6.6 \%(4.5 \%, 8.7 \%)\end{array}$ & $\begin{array}{l}3.85(2.65,5.06) \\
0.37 \%(0.25 \%, 0.48 \%) \\
7.2 \%(4.9 \%, 9.4 \%)\end{array}$ & $\begin{array}{l}4.73(3.25,6.20) \\
0.46 \%(0.32 \%, 0.61 \%) \\
8 \%(5.5 \%, 10.6 \%)\end{array}$ \\
\hline & Cars in NYC & $\begin{array}{l}1.41(0.97,1.85) \\
0.16 \%(0.11 \%, 0.20 \%) \\
3.1 \%(2.2 \%, 4.1 \%)\end{array}$ & $\begin{array}{l}1.75(1.20,2.29) \\
0.19 \%(0.13 \%, 0.25 \%) \\
3.8 \%(2.6 \%, 4.9 \%)\end{array}$ & $\begin{array}{l}2.18(1.50,2.86) \\
0.21 \%(0.14 \%, 0.27 \%) \\
4 \%(2.8 \%, 5.3 \%)\end{array}$ & $\begin{array}{l}2.87(1.98,3.77) \\
0.28 \%(0.19 \%, 0.37 \%) \\
4.9 \%(3.4 \%, 6.4 \%)\end{array}$ \\
\hline & All on-road mobile sources outside NYC & $\begin{array}{l}1.35(0.93,1.78) \\
0.15 \%(0.10 \%, 0.20 \%) \\
3.0 \%(2.1 \%, 4.0 \%)\end{array}$ & $\begin{array}{l}1.05(0.72,1.37) \\
0.11 \%(0.08 \%, 0.15 \%) \\
2.3 \%(1.5 \%, 3.0 \%)\end{array}$ & $\begin{array}{l}1.33(0.91,1.74) \\
0.13 \%(0.09 \%, 0.17 \%) \\
2.5 \%(1.7 \%, 3.2 \%)\end{array}$ & $\begin{array}{l}1.38(0.95,1.81) \\
0.13 \%(0.09 \%, 0.18 \%) \\
2.4 \%(1.6 \%, 3.1 \%)\end{array}$ \\
\hline \multirow{5}{*}{$\begin{array}{l}\text { Impacts on Emergency Department Visits for } \\
\text { Asthma among all residents } \\
\left(\mathrm{PM}_{2.5} \text {-attributable rate per } 100,000 \text { residents }\right. \\
(95 \% \mathrm{Cl} \text { ), } \\
\text { Percent of all events ( } 95 \% \mathrm{Cl} \text { ) } \\
\text { Percent of } \mathrm{PM}_{2.5} \text {-attributable events }(95 \% \mathrm{Cl} \text { ) }\end{array}$} & All on-road mobile sources in region & $\begin{array}{l}2.39(1.4,3.39) \\
0.64 \%(0.37 \%, 0.9 \%) \\
10.8 \%(6.3 \%, 15.3 \%)\end{array}$ & $\begin{array}{l}4.64(2.71,6.58) \\
0.7 \%(0.41 \%, 1 \%) \\
12 \%(7 \%, 17 \%)\end{array}$ & $\begin{array}{l}9.54(5.51,13.56) \\
0.76 \%(0.44 \%, 1.09 \%) \\
13.2 \%(7.6 \%, 18.7 \%)\end{array}$ & $\begin{array}{l}19.97(11.37,28.56) \\
0.83 \%(0.47 \%, 1.18 \%) \\
14.2 \%(8.1 \%, 20.3 \%)\end{array}$ \\
\hline & All on-road mobile sources in NYC & $\begin{array}{l}1.79(1.04,2.53) \\
0.48 \%(0.28 \%, 0.67 \%) \\
8.1 \%(4.7 \%, 11.4 \%)\end{array}$ & $\begin{array}{l}3.87(2.26,5.47) \\
0.59 \%(0.34 \%, 0.83 \%) \\
10 \%(5.8 \%, 14.1 \%)\end{array}$ & $\begin{array}{l}7.89(4.57,11.19) \\
0.63 \%(0.37 \%, 0.9 \%) \\
10.9 \%(6.3 \%, 15.5 \%)\end{array}$ & $\begin{array}{l}16.96(9.66,24.23) \\
0.7 \%(0.4 \%, 1 \%) \\
12.1 \%(6.9 \%, 17.3 \%)\end{array}$ \\
\hline & Trucks and buses in NYC & $\begin{array}{l}1.17(0.7,1.65) \\
0.31 \%(0.19 \%, 0.44 \%) \\
5.3 \%(3.2 \%, 7.5 \%)\end{array}$ & $\begin{array}{l}2.58(1.54,3.62) \\
0.39 \%(0.23 \%, 0.55 \%) \\
6.7 \%(4 \%, 9.4 \%)\end{array}$ & $\begin{array}{l}5.21(3.09,7.32) \\
0.42 \%(0.25 \%, 0.59 \%) \\
7.2 \%(4.3 \%, 10.1 \%)\end{array}$ & $\begin{array}{l}10.98(6.42,15.54) \\
0.45 \%(0.27 \%, 0.64 \%) \\
7.8 \%(4.6 \%, 11.1 \%)\end{array}$ \\
\hline & Cars in NYC & $\begin{array}{l}0.61(0.34,0.88) \\
0.16 \%(0.09 \%, 0.23 \%) \\
2.8 \%(1.5 \%, 4 \%)\end{array}$ & $\begin{array}{l}1.29(0.72,1.85) \\
0.19 \%(0.11 \%, 0.28 \%) \\
3.3 \%(1.8 \%, 4.8 \%)\end{array}$ & $\begin{array}{l}2.68(1.48,3.87) \\
0.21 \%(0.12 \%, 0.31 \%) \\
3.7 \%(2 \%, 5.3 \%)\end{array}$ & $\begin{array}{l}5.97(3.25,8.69) \\
0.25 \%(0.13 \%, 0.36 \%) \\
4.3 \%(2.3 \%, 6.2 \%)\end{array}$ \\
\hline & All on-road mobile sources outside NYC & $\begin{array}{l}0.61(0.36,0.86) \\
0.16 \%(0.1 \%, 0.23 \%) \\
2.7 \%(1.6 \%, 3.9 \%)\end{array}$ & $\begin{array}{l}0.78(0.45,1.1) \\
0.12 \%(0.07 \%, 0.17 \%) \\
2 \%(1.2 \%, 2.8 \%)\end{array}$ & $\begin{array}{l}1.65(0.94,2.36) \\
0.13 \%(0.08 \%, 0.19 \%) \\
2.3 \%(1.3 \%, 3.3 \%)\end{array}$ & $\begin{array}{l}3.02(1.7,4.33) \\
0.12 \%(0.07 \%, 0.18 \%) \\
2.1 \%(1.2 \%, 3.1 \%)\end{array}$ \\
\hline
\end{tabular}


Table 2 Distribution of $\mathrm{PM}_{25}$-attributable health outcomes due to on-road mobile sources by area poverty (Continued)

\begin{tabular}{|c|c|c|c|c|c|}
\hline \multirow{5}{*}{$\begin{array}{l}\text { Impacts on Hospitalizations for Cardiovascular } \\
\text { Disease among residents over } 40 \text { years of age. } \\
\text { (PM } 2.5 \text {-attributable rate per 100,000 residents } \\
(95 \% \mathrm{Cl} \text { ), } \\
\text { Percent of all events ( } 95 \% \mathrm{Cl}) \\
\text { Percent of PM } \text { P }_{2.5} \text {-attributable events ( } 95 \% \mathrm{Cl} \text { ) }\end{array}$} & All on-road mobile sources in region & $\begin{array}{l}1.59(0.39,2.78) \\
0.12 \%(0.03 \%, 0.21 \%) \\
11.5 \%(2.8 \%, 20.3 \%)\end{array}$ & $\begin{array}{l}2.12(0.52,3.71) \\
0.13 \%(0.03 \%, 0.23 \%) \\
12.7 \%(3.1 \%, 22.3 \%)\end{array}$ & $\begin{array}{l}2.74(0.68,4.8) \\
0.15 \%(0.04 \%, 0.26 \%) \\
13.7 \%(3.4 \%, 24 \%)\end{array}$ & $\begin{array}{l}3.81(0.96,6.66) \\
0.18 \%(0.05 \%, 0.32 \%) \\
15.3 \%(3.8 \%, 26.7 \%)\end{array}$ \\
\hline & All on-road mobile sources in NYC & $\begin{array}{l}1.15(0.28,2.02) \\
0.09 \%(0.02 \%, 0.15 \%) \\
8.4 \%(2.1 \%, 14.7 \%)\end{array}$ & $\begin{array}{l}1.75(0.43,3.07) \\
0.11 \%(0.03 \%, 0.19 \%) \\
10.5 \%(2.6 \%, 18.4 \%)\end{array}$ & $\begin{array}{l}2.25(0.56,3.94) \\
0.12 \%(0.03 \%, 0.22 \%) \\
11.2 \%(2.8 \%, 19.7 \%)\end{array}$ & $\begin{array}{l}3.23(0.81,5.64) \\
0.15 \%(0.04 \%, 0.27 \%) \\
12.9 \%(3.2 \%, 22.6 \%)\end{array}$ \\
\hline & Trucks and buses in NYC & $\begin{array}{l}0.72(0.17,1.28) \\
0.05 \%(0.01 \%, 0.09 \%) \\
5.3 \%(1.2 \%, 9.3 \%)\end{array}$ & $\begin{array}{l}1.1(0.26,1.94) \\
0.07 \%(0.02 \%, 0.12 \%) \\
6.6 \%(1.6 \%, 11.6 \%)\end{array}$ & $\begin{array}{l}1.42(0.34,2.5) \\
0.08 \%(0.02 \%, 0.14 \%) \\
7.1 \%(1.7 \%, 12.5 \%)\end{array}$ & $\begin{array}{l}1.99(0.48,3.49) \\
0.1 \%(0.02 \%, 0.17 \%) \\
8 \%(1.9 \%, 14 \%)\end{array}$ \\
\hline & Cars in NYC & $\begin{array}{l}0.43(0.11,0.75) \\
0.03 \%(0.01 \%, 0.06 \%) \\
3.1 \%(0.8 \%, 5.4 \%)\end{array}$ & $\begin{array}{l}0.65(0.17,1.13) \\
0.04 \%(0.01 \%, 0.07 \%) \\
3.9 \%(1 \%, 6.8 \%)\end{array}$ & $\begin{array}{l}0.83(0.22,1.45) \\
0.05 \%(0.01 \%, 0.08 \%) \\
4.2 \%(1.1 \%, 7.2 \%)\end{array}$ & $\begin{array}{l}1.24(0.33,2.15) \\
0.06 \%(0.02 \%, 0.1 \%) \\
5 \%(1.3 \%, 8.6 \%)\end{array}$ \\
\hline & All on-road mobile sources outside NYC & $\begin{array}{l}0.43(0.1,0.76) \\
0.03 \%(0.01 \%, 0.06 \%) \\
3.2 \%(0.8 \%, 5.5 \%)\end{array}$ & $\begin{array}{l}0.37(0.09,0.65) \\
0.02 \%(0.01 \%, 0.04 \%) \\
2.2 \%(0.6 \%, 3.9 \%)\end{array}$ & $\begin{array}{l}0.49(0.12,0.86) \\
0.03 \%(0.01 \%, 0.05 \%) \\
2.5 \%(0.6 \%, 4.3 \%)\end{array}$ & $\begin{array}{l}0.58(0.15,1.01) \\
0.03 \%(0.01 \%, 0.05 \%) \\
2.3 \%(0.6 \%, 4.1 \%)\end{array}$ \\
\hline \multirow{5}{*}{$\begin{array}{l}\text { Impacts on Hospitalizations for Respiratory } \\
\text { Disease among residents above } 20 \text { years of age } \\
\text { (PM } 2.5 \text {-attributable rate per 100,000 residents } \\
(95 \% \mathrm{Cl} \text { ), } \\
\text { Percent of all events }(95 \% \mathrm{Cl} \text { ) } \\
\text { Percent of } \mathrm{PM}_{2.5} \text {-attributable events ( } 95 \% \mathrm{Cl} \text { ) }\end{array}$} & All on-road mobile sources in region & $\begin{array}{l}1.13(0.42,1.85) \\
0.55(0.22,0.89) \\
11 \%(4.1 \%, 18 \%)\end{array}$ & $\begin{array}{l}1.44(0.55,2.34) \\
0.25 \%(0.09 \%, 0.4 \%) \\
12.1 \%(4.6 \%, 19.6 \%)\end{array}$ & $\begin{array}{l}2.04(0.8,3.29) \\
0.28 \%(0.11 \%, 0.46 \%) \\
13.4 \%(5.2 \%, 21.5 \%)\end{array}$ & $\begin{array}{l}3.58(1.43,5.71) \\
0.33 \%(0.13 \%, 0.52 \%) \\
14.7 \%(5.9 \%, 23.5 \%)\end{array}$ \\
\hline & All on-road mobile sources in NYC & $\begin{array}{l}0.84(0.31,1.37) \\
0.16 \%(0.06 \%, 0.27 \%) \\
8.1 \%(3 \%, 13.3 \%)\end{array}$ & $\begin{array}{l}1.19(0.45,1.93) \\
0.2 \%(0.08 \%, 0.33 \%) \\
10 \%(3.8 \%, 16.1 \%)\end{array}$ & $\begin{array}{l}1.69(0.66,2.71) \\
0.23 \%(0.09 \%, 0.38 \%) \\
11 \%(4.3 \%, 17.7 \%)\end{array}$ & $\begin{array}{l}3.02(1.21,4.83) \\
0.28 \%(0.11 \%, 0.44 \%) \\
12.4 \%(5 \%, 19.8 \%)\end{array}$ \\
\hline & Trucks and buses in NYC & $\begin{array}{l}0.54(0.2,0.88) \\
0.11 \%(0.04 \%, 0.17 \%) \\
5.3 \%(1.9 \%, 8.6 \%)\end{array}$ & $\begin{array}{l}0.77(0.29,1.24) \\
0.13 \%(0.05 \%, 0.21 \%) \\
6.4 \%(2.4 \%, 10.4 \%)\end{array}$ & $\begin{array}{l}1.08(0.42,1.74) \\
0.15 \%(0.06 \%, 0.24 \%) \\
7.1 \%(2.8 \%, 11.4 \%)\end{array}$ & $\begin{array}{l}1.87(0.75,2.99) \\
0.17 \%(0.07 \%, 0.27 \%) \\
7.7 \%(3.1 \%, 12.3 \%)\end{array}$ \\
\hline & Cars in NYC & $\begin{array}{l}0.3(0.11,0.48) \\
0.06 \%(0.02 \%, 0.1 \%) \\
2.9 \%(1.1 \%, 4.7 \%)\end{array}$ & $\begin{array}{l}0.42(0.16,0.69) \\
0.07 \%(0.03 \%, 0.12 \%) \\
3.5 \%(1.3 \%, 5.8 \%)\end{array}$ & $\begin{array}{l}0.6(0.23,0.97) \\
0.08 \%(0.03 \%, 0.13 \%) \\
3.9 \%(1.5 \%, 6.3 \%)\end{array}$ & $\begin{array}{l}1.15(0.46,1.84) \\
0.11 \%(0.04 \%, 0.17 \%) \\
4.7 \%(1.9 \%, 7.5 \%)\end{array}$ \\
\hline & All on-road mobile sources outside NYC & $\begin{array}{l}0.3(0.11,0.48) \\
0.06 \%(0.02 \%, 0.09 \%) \\
2.9 \%(1.1 \%, 4.7 \%)\end{array}$ & $\begin{array}{l}0.25(0.09,0.41) \\
0.04 \%(0.02 \%, 0.07 \%) \\
2.1 \%(0.8 \%, 3.4 \%)\end{array}$ & $\begin{array}{l}0.36(0.14,0.58) \\
0.05 \%(0.02 \%, 0.08 \%) \\
2.4 \%(0.9 \%, 3.8 \%)\end{array}$ & $\begin{array}{l}0.55(0.22,0.89) \\
0.05 \%(0.02 \%, 0.08 \%) \\
2.3 \%(0.9 \%, 3.6 \%)\end{array}$ \\
\hline \multirow[t]{4}{*}{ Baseline Outcome Rates (rate per 100,000 residents) } & $\begin{array}{l}\text { All-cause mortality } \\
\text { (ages } 30 \text { and above) }\end{array}$ & 907.5 & 934.2 & 1051.1 & 1024.6 \\
\hline & $\begin{array}{l}\text { Emergency department visits for } \\
\text { asthma (all ages) }\end{array}$ & 374.9 & 659.5 & 1248.4 & 2416.1 \\
\hline & $\begin{array}{l}\text { Hospitalizations for cardiovascular } \\
\text { disease (ages } 40 \text { and above) }\end{array}$ & 1354.9 & 1589.3 & 1824.5 & 2089.1 \\
\hline & $\begin{array}{l}\text { Hospitalizations for respiratory } \\
\text { disease (ages } 20 \text { and above) }\end{array}$ & 508.9 & 589.0 & 722.8 & 1089.0 \\
\hline
\end{tabular}
disease (ages 20 and above) (ages 30 and above)

Emergency department visits for

(diovascular 
heavy duty diesel trucks and buses. We found that these sources contribute to $7.5 \%$ of the ambient levels of $\mathrm{PM}_{2.5}$ in high poverty neighborhoods and up to $0.6 \%$ of all deaths in the most affected neighborhood. Traffic from counties in the region outside of NYC showed less of an impact on local $\mathrm{PM}_{2.5}$ concentrations, which were evenly distributed across neighborhoods of varying poverty status.

Prior work in other cities and nationally has also explored the air quality and public health impacts of traffic. A nationwide analysis indicted that all mobile sources (including all non-road, aircraft, locomotive, marine vessels, and ocean-going vessels) could contribute to $17,000 \mathrm{PM}_{2.5}$-attributable deaths in 2016 [6]. Other research has pointed to the importance of trafficrelated $\mathrm{PM}_{2.5}$ on mortality, suggesting that in 2005 traffic emissions contributed to $3000 \mathrm{PM}_{2.5}$-attributable deaths nationally [8]. Applying a similar air quality and health modeling framework as was used in this analysis, additional research has suggested significant regional benefits to eliminating motor vehicle trips [38]. Prior natural experiments on removal of traffic in urban areas during events have shown some associated improvements in air quality, although the benefits are often pollutant specific and vary based on the situation being studied, particularly when evaluating pollutants with strong regional contributions such as $\mathrm{PM}_{2.5}[39,40]$. Source apportionment analyses conducted using data from the early 2000s from a few monitoring locations in the region suggested that $16-39 \%$ of ambient $\mathrm{PM}_{2.5}$ concentrations in NYC are attributable to traffic sources $[10,11]$. These estimates are higher than those found in this analysis, potentially due to the limitations in the numbers of monitors used in the source-apportionment studies (where monitoring sites are skewed to high emissions locations) and newer traffic emissions estimates that reflect lower emissions from on-road mobile sources in more recent years. To our knowledge this is the first analysis in this region that explicitly examines impacts of differing types of vehicles at a high spatial resolution across neighborhoods within an urban area, which provides valuable insight when exploring effective emissions control strategies.

This analysis also provides a new perspective on variation in $\mathrm{PM}_{2.5}$ exposures across populations of differing socioeconomic status (SES). Prior work has found that higher SES communities in NYC experience higher overall $\mathrm{PM}_{2.5}$ and $\mathrm{NO}_{2}$ exposures, due to the confluence of building and traffic sources in high-income areas, a pattern that is unusual among major metropolitan areas where lower SES areas often experience higher pollutant exposures [41, 42]. In contrast to the pattern for total $\mathrm{PM}_{2.5}$, on-road mobile source-attributable $\mathrm{PM}_{2.5}$ concentrations are higher in low-income neighborhoods of the city, indicating that efforts to reduce exposures in these burdened communities should be focused on on-road mobile source-related programs.

We find that measures to reduce emissions from heavy-duty vehicles within NYC should be prioritized, particularly those traveling roadways in neighborhoods with high densities of susceptible populations and low income residents. Studies conducted in other cities have shown success implementing congestion charging schemes or low-emissions zones that target the most polluting trucks and buses [43, 44], with differing observations on the distribution of benefits by socioeconomic status, depending on the location evaluated $[45,46]$. In designing congestion mitigation schemes, this analysis suggests a focus on NYC as a whole and on heavy-duty diesel vehicles would yield significantly greater health benefits, as opposed to focusing on vehicles in the most congested urban core. Measures to reduce VMTs and emissions from trucks and buses within the city may need to address trips from all types of vehicles originating inside and outside of the city. For example, in the Hunt's Point section of the South Bronx, an area with high burdens of $\mathrm{PM}_{2.5}$-attributable morbidity and mortality from truck emissions, an estimated $57 \%$ of trucks servicing the meat and produce market (one of the largest food distribution centers in the world) came from outside of the city [47]. Other surveys have suggested $20 \%$ of car miles traveled in NYC are from trips originating outside of the city [48]. While direct emissions from cars have less of an impact on air quality and health compared to heavy duty diesel vehicles, car trips contribute to congestion, which increases diesel emissions on routes shared with trucks and buses.

While this study offers new insights and methods for assessing $\mathrm{PM}_{2.5}$-attributable health impacts, there are some limitations. The confidence intervals described in our results reflect only the confidence intervals reported in the risk estimates derived from the epidemiologic studies and do not account for uncertainties in the other steps of the analysis. EPA's inventory estimates are subject to uncertainties in emissions factors, vehicle mix, and activity. Despite likely simulating spatial gradients in emissions better than other commonly used surrogates such as road density, they may not fully account for higher emissions in low speed stop-and-go traffic within the congested urban core. Future work would benefit for more precise estimates of emissions at a neighborhoodlevel. The meteorological and air quality simulations also carry uncertainties common in these types of studies. Prior evaluation of the base case modeling, however, showed that the WRF and CMAQ models performed within recommended bias and precision benchmarks [18]. A strength of our study is that it employs $1-\mathrm{km} \mathrm{PM}_{2.5}$ exposure modeling, a higher resolution than prior studies 
of this type and thus better accounts for within-city variations in susceptibility. This provides new methods and insight into how source-specific impacts can vary within an urban area and among populations of differing socioeconomic status. Despite this, 1-km resolution may not fully capture microscale, near-roadway exposures that can vary within several hundred meters of the roadway $[49,50]$.

Our health impact estimates include common limitations described elsewhere [28] some of which have been addressed by using neighborhood-level health outcome data. We have utilized epidemiological studies that assume uniform relative risk across all neighborhoods with varying traffic density. Emerging research has suggested stronger associations between asthma morbidity and air pollutant exposures in higher traffic areas (implying that $\mathrm{PM}_{2.5}$ emissions from traffic may be more toxic), and such effect modification research is a field of ongoing study [51]. Similarly, while our analyses applied risk estimates based on total $\mathrm{PM}_{2.5}$ exposures, recent analyses of the ACS cohort has suggested higher chronic mortality risk associated with $\mathrm{PM}_{2.5}$ with higher sulfur content [52]. As more evidence accumulates we will evaluate the sensitivity of our burden estimates to varying risk functions, and future work will evaluate how variations in neighborhood-level risk contribute to disparities in impacts across the City. While this analysis has leveraged associations between $\mathrm{PM}_{2.5}$ and excess emergency department visits and hospitalizations, studies have shown that air pollution exposures can also contribute to new cases of asthma [53], suggesting morbidity estimates in this analysis are conservative. Finally, our analysis focused only on the impacts of on-road mobile source emissions on $\mathrm{PM}_{2.5}$ associated mortality and select cardio-respiratory outcomes and does not account for the wide range of additional negative effects of motor vehicle traffic and congestion, including health effects associated with other pollutants and noise, contributions to greenhouse gas emissions, risk of pedestrian and other injury, and time wasted.

\section{Conclusion}

Local scale air quality and public health modeling can provide valuable information on the contribution of sources to pollution-attributable health and disparity within an urban area. In this study, we presented a methodology for assessing the public health impacts of traffic in cities, and evaluating these impacts across populations with varying underlying health and socioeconomic status. In applying these methods in NYC, we found that air pollutant emissions from on-road mobile sources contribute to hundreds of preventable $\mathrm{PM}_{2.5}$-attributable deaths, hospitalizations, and emergency department visits among residents of NYC, with disproportionate impacts in high poverty neighborhoods, indicating that increased policy efforts should focus on the most polluting vehicles in these neighborhoods.

\section{Additional file}

Additional file 1: Table S1. Contributions of source categories to primary and secondary $\mathrm{PM}_{2.5}$ levels at grid cells within New York City. (DOCX $13 \mathrm{~kb})$

\section{Acknowledgments}

We thank Sarah Johnson of NYC DOHMH for assisting in the spatial allocation of mobile source emissions and Kazue Anan of NYC DOHMH for help with figures. We also appreciate the assistance of Wenhui Li and Gil Maduro of the NYC DOHMH Office of Vital Statistics in developing the life tables used in this analysis.

\section{Funding}

This work was supported by New York City tax levy funds.

\section{Availability of data and materials}

Emissions data used in this analysis are publically available via https:// www.epa.gov/air-emissions-inventories. Authors are not authorized to share baseline health data or traffic data, but can be accessed through formal requests to the New York City Department of Health's Office of Vital Statistics, the New York State Statewide Planning and Research Cooperative System, and the New York Metropolitan Transportation Council. Air pollution monitoring data is publically available through https://www.epa.gov/aqs.

\section{Authors' contributions}

IK contributed to study design, data analysis, and led drafting and editing the manuscript. JH and SD led air quality modeling analyses and contributed to study design, data analysis and editing the manuscript. KI contributed to study design, interpreting results and drafting and editing the manuscript.

TM oversaw the method development and data analysis and contributed to drafting and editing the manuscript. All authors participated in interpretation of the results and all authors read and approved the final manuscript.

Competing interests

The authors declare that they have no competing interests.

Consent for publication

Not applicable.

Ethics approval and consent to participate

Not applicable.

\section{Author details}

${ }^{1}$ New York City Department of Health and Mental Hygiene, Bureau of Environmental Surveillance and Policy, 125 Worth Street, Third Flr. CN-34E, New York, NY 10013, USA. ${ }^{2}$ ICF International, 101 Lucas Valley Road, Suite 260, San Rafael, CA 94903, USA.

Received: 16 March 2016 Accepted: 12 August 2016

Published online: 26 August 2016

\section{References}

1. USEPA. Integrated science assessment for particulate matter. US Environmental Protection Agency. 2009. https://cfpub.epa.gov/ncea/risk/ recordisplay.cfm?deid=216546. Accessed 9 Aug 2016.

2. Kheirbek I, Johnson S, Ito K, Matte T, Kass D, Caputo Jr S, Mahnovski S, CH S, Licata A, Eisl H, et al. New York City Trends in Air Pollution and its Health Consequences. New York City Department of Health and Mental Hygiene. 2013. https://www1.nyc.gov/assets/doh/downloads/pdf/environmental/airquality-report-2013.pdf. Accessed 9 Aug 2016.

3. HEl. Traffic-Related Air Pollution: A Critical Review of the Literature on Emissions, Exposure, and Health Effects HEl Panel on the Health Effects of Traffic-Related Air Pollution. Health Effects Institute. 2010. http://pubs. healtheffects.org/getfile.php?u=553. Accessed 9 Aug 2016.

4. Brugge D, Durant JL, Rioux C. Near-highway pollutants in motor vehicle exhaust: a review of epidemiologic evidence of cardiac and pulmonary health risks. Environ Health. 2007;6:23. 
5. Lin S, Munsie JP, Hwang S-A, Fitzgerald E, Cayo MR. Childhood asthma hospitalization and residential exposure to state route traffic. Environ Res. 2002;88:73-81.

6. Fann N, Fulcher CM, Baker K. The recent and future health burden of air pollution apportioned across US sectors. Environ Sci Technol. 2013:47:3580-9.

7. Grabow ML, Spak SN, Holloway T, Stone B, Mednick AC, Patz JA. Air quality and exercise-related health benefits from reduced car travel in the midwestern United States. Environ Health Perspect. 2012;120:68-76.

8. Levy Jl, Buonocore JJ, Von Stackelberg K. Evaluation of the public health impacts of traffic congestion: a health risk assessment. Environ Health. 2010;9:65.

9. USEPA. Regulatory Impact Analysis: Final Rulemaking for 2017-2025 LightDuty Vehicle Greenhouse Gas Emission Standards and Corporate Average Fuel Economy Standards. US Environmental Protection Agency. 2012. https://www3.epa.gov/otaq/climate/documents/420r12016.pdf. Accessed 9 Aug 2016

10. Ito K, Xue N, Thurston G. Spatial variation of PM2.5 chemical species and source-apportioned mass concentrations in New York City. Atmos Environ. 2004;38:31.

11. Lall R, Thurston GD. Identifying and quantifying transported vs. local sources of New York City fine particulate matter air pollution. Atmos Environ. 2006: 40:333-46.

12. Clougherty JE, Kheirbek I, Eisl HM, Ross Z, Pezeshki G, Gorczynski JE, Johnson S, Markowitz S, Kass D, Matte T. Intra-urban spatial variability in wintertime street-level concentrations of multiple combustion-related air pollutants: the New York City Community Air Survey (NYCCAS). J Expo Sci Environ Epidemiol. 2013;23:3.

13. Cook R, Isakov V, Touma JS, Benjey W, Thurman J, Kinnee E, Ensley D. Resolving local-scale emissions for modeling air quality near roadways. J Air Waste Manag Assoc. 2008;58:3.

14. Kheirbek I, Haney J, Douglas S, Ito K, Caputo Jr S, Matte T. The public health benefits of reducing fine particulate matter through conversion to cleaner heating fuels in New York City. Environ Sci Technol. 2014;48:13573-82.

15. NYC. PlaNYC: Update April 2011. A Greener, Greater New York. The City of New York. 2011. http://www.nyc.gov/html/planyc/downloads/pdf/ publications/planyc 2011_planyc full_report.pdf. Accessed 9 Aug 2016.

16. Environment \& Health Data Portal. New York City Department of Health. http://a816-dohbesp.nyc.gov/IndicatorPublic/PublicTracking.aspx. Accessed 9 Aug 2016.

17. NYC. One New York: The Plan for a Strong and Just City. The City of New York. 2015. http://www1.nyc.gov/html/onenyc/index.html. Accessed 9 Aug 2016.

18. ICF International. High-Resolution Air Quality Modeling of New York City to Assess the Effects of Changes in Fuels for Boilers and Power Generation. ICF International. 2014. www.nyccleanheat.org/sites/default/files/public/NYC_ High_Resolution_AQM_Final_23June2014.pdf. Accessed 9 Aug 2016.

19. USEPA. 2008 National Emissions Inventory. United States Environmental Protection Agency. https://www.epa.gov/air-emissions-inventories/2008national-emissions-inventory-nei-data. Accessed 9 Aug 2016.

20. USEPA. 2011 National Emissions Inventory. United States Environmental Protection Agency. https://www.epa.gov/air-emissions-inventories/2011national-emissions-inventory-nei-data. Accessed 9 Aug 2016.

21. New York Metropolitan Transportation Council. Best Practices Model. 2005. https://www.nymtc.org/Data-and-Modeling/New-York-Best-Practice-ModelNYBPM. Accessed 9 Aug 2016.

22. USEPA. 2008 Modeling Platform. ftp://ftp.epa.gov/EmisInventory/2007v5. Accessed 9 Aug 2016.

23. USEPA. AP-42, Fifth Edition, Volume I. Chapter 1: External Combustion Sources. US Environmental Protection Agency. 2010. https://www3.epa.gov/ ttn/chief/ap42/ch01/index.html. Accessed 9 Aug 2016.

24. New York State. New York Codes, Rules and Regulations Subpart 225-1, Fuel Composition and Use; Sulfur Limitations. New York State Department of Environmental Protection. 2012. https://govt.westlaw.com/nycrr/Browse/ Home/NewYork/NewYorkCodesRulesandRegulations?guid=lb74b1990b 5a011dda0a4e17826ebc834\&originationContext=documenttoc \&transitionType=Default\&contextData=(sc.Default). Accessed 9 Aug 2016.

25. NYC Clean Heat Program. http://www.nyccleanheat.org/. Accessed 9 Aug 2016.

26. Abt Associates. Modeled Attainment Test Software. Abt Associates Inc. 2010 https://www3.epa.gov/scram001/modelingapps_mats.htm. Accessed 9 Aug 2016.

27. Kheirbek I, Wheeler K, Walters S, Kass D, Matte T. PM2.5 and ozone health impacts and disparities in New York City: sensitivity to spatial and temporal resolution. Air Qual Atmos Health. 2013;6:473-86.
28. Hubbell B, Fann N, Levy Jl. Methodological considerations in developing local-scale health impact assessments: balancing national, regional, and local data. Air Qual Atmos Health. 2009;2:99-110.

29. Krewski D, Jerrett M, Burnett RT, Ma R, Hughes E, Shi Y, Turner MC, Pope III CA, Thurston G, Calle EE. Extended follow-up and spatial analysis of the American Cancer Society study linking particulate air pollution and mortality. Health Effects Institute. 2009. http://www.healtheffects.org/Pubs/ RR140-Krewski.pdf. Accessed 9 Aug 2016.

30. Ito K, Thurston GD, Silverman RA. Characterization of PM2.5, gaseous pollutants, and meteorological interactions in the context of time-series health effects models. J Expo Sci Environ Epidemiol. 2007;17 Suppl 2:45-60.

31. Moolgavkar SH. Air pollution and hospital admissions for chronic obstructive pulmonary disease in three metropolitan areas in the United States. Inhal Toxicol. 2000;12 Suppl 4:75-90.

32. Zanobetti $\mathrm{A}$, Franklin $\mathrm{M}$, Koutrakis $\mathrm{P}$, Schwartz J. Fine particulate air pollution and its components in association with cause-specific emergency admissions. Environ Health. 2009;8:58.

33. Ito K, Mathes R, Ross Z, Nádas A, Thurston G, Matte T. Fine particulate matter constituents associated with cardiovascular hospitalizations and mortality in New York City. Environ Health Perspect. 2011;119:4.

34. US EPA. Quantitative health risk assessment for particulate matter. US Environmental Protection Agency: Office of Air Quality Planning and Standards. 2010. https://www3.epa.gov/ttn/naaqs/standards/pm/data/PM RA_FINAL_June_2010.pdf. Accessed 9 Aug 2016.

35. New York City Department of Health and Mental Hygiene. Epiquery: NYC Interactive Health Data System - NYCDOHMH neighborhood population estimates, modified from the US Census Bureau vintage population estimates. http://www1.nyc.gov/site/doh/data/health-tools/nyc-population. page. Accessed 9 Aug 2016.

36. USEPA. Environmental Benefits Mapping and Analysis Program (BenMAP) http://www.epa.gov/benmap. Accessed 9 Aug 2016.

37. Arias E. United States Life Tabels, 2010. US Department of Health and Human Services Centers for Disease Control and Prevention. 2010. http:// www.cdc.gov/nchs/data/nvsr/nvsr63/nvsr63 07.pdf. Accessed 9 Aug 2016.

38. Grabow ML, Spak SN, Holloway T, Stone Jr B, Mednick AC, Patz JA. Air quality and exercise-related health benefits from reduced car travel in the midwestern United States. Environ Health Perspect. 2012;120:1.

39. Friedman MS, Powell KE, Hutwagner L, Graham LM, Teague WG. Impact of changes in transportation and commuting behaviors during the 1996 Summer Olympic Games in Atlanta on air quality and childhood asthma. JAMA. 2001;285:897-905.

40. Hong A, Schweitzer L, Yang W, Marr LC. Impact of temporary freeway closure on regional air quality: a lesson from Carmageddon in Los Angeles, United States. Environ Sci Technol. 2015:49:3211-8.

41. Shmool JL, Bobb JF, Ito K, Elston B, Savitz DA, Ross Z, Matte TD, Johnson S, Dominici F, Clougherty JE. Area-level socioeconomic deprivation, nitrogen dioxide exposure, and term birth weight in New York City. Environ Res. 2015;142:624-32.

42. Hajat A, Diez-Roux AV, Adar SD, Auchincloss AH, Lovasi GS, O'Neill MS, Sheppard L, Kaufman JD. Air pollution and individual and neighborhood socioeconomic status: evidence from the Multi-Ethnic Study of Atherosclerosis (MESA). Environ Health Perspect. 2013;121:1325-33.

43. Johansson C, Burman L, Forsberg B. The effects of congestions tax on air quality and health. Atmos Environ. 2009;43:4843-54.

44. Jones AM, Harrison RM, Barratt B, Fuller G. A large reduction in airborne particle number concentrations at the time of the introduction of "sulphur free" diesel and the London Low Emission Zone. Atmos Environ. 2012:50:129-38

45. Cesaroni G, Boogaard H, Jonkers S, Porta D, Badaloni C, Cattani G, Forastiere $F$. Hoek $G$. Health benefits of traffic-related air pollution reduction in different socioeconomic groups: the effect of low-emission zoning in Rome. Occup Environ Med. 2012;69:133-9.

46. Tonne C, Beevers S, Armstrong B, Kelly F, Wilkinson P. Air pollution and mortality benefits of the London Congestion Charge: spatial and socioeconomic inequalities. Occup Environ Med. 2008;65:620-7.

47. URS. Hunts Point Truck Study. URS/Goodkind \& O'Dea, Inc. https://www.dot ny.gov/regional-offices/region11/projects/project-repository/bese/pdf/hp_ p1.pdf. Accessed 9 Aug 2016.

48. Schaller Consulting. CITYinFLUX: Understanding and Untangling Traffic and Transportation in New York City. Schaller Consulting. 2007. http://www. schallerconsult.com/pub/cityinflux.pdf. Accessed 9 Aug 2016. 
49. Greco SL, Wilson AM, Hanna SR, Levy Jl. Factors influencing mobile source particulate matter emissions-to-exposure relationships in the Boston urban area. Environ Sci Technol. 2007:41:7675-82.

50. Karner AA, Eisinger DS, Niemeier DA. Near-roadway air quality: synthesizing the findings from real-world data. Environ Sci Technol. 2010;44:5334-44.

51. Delfino RJ, Wu J, Tjoa T, Gullesserian SK, Nickerson B, Gillen DL. Asthma morbidity and ambient air pollution: effect modification by residential traffic-related air pollution. Epidemiol. 2014;25:48-57.

52. Thurston GD, Ito K, Lall R, Burnett RT, Turner MC, Krewski D, Shi Y, Jerrett M, Gapstur S, Driver R, et al. NPACT Study 4: Mortality and Long-Term Exposure to PM2.5 and its Components in the American Cancer Society's Cancer Prevention Study II Cohort. In: National Particle Component Toxicity (NPACT) Initiative: Integrated Epidemiologic and Toxicologic Studies of the Health Effects of Particulate Matter Components. Health Effect Institute. 2013. http://pubs.healtheffects.org/getfile.php?u=934. Accessed 9 Aug 2016.

53. McConnell R, Islam T, Shankardass K, Jerrett M, Lurmann F, Gilliland F, Gauderman J, Avol E, Künzli N, Yao L. Childhood incident asthma and traffic-related air pollution at home and school. Environ Health Perspect. 2010;118:1021-6.

\section{Submit your next manuscript to BioMed Central} and we will help you at every step:

- We accept pre-submission inquiries

- Our selector tool helps you to find the most relevant journal

- We provide round the clock customer support

- Convenient online submission

- Thorough peer review

- Inclusion in PubMed and all major indexing services

- Maximum visibility for your research

Submit your manuscript at www.biomedcentral.com/submit 